\title{
Achievements in breeding coconut hybrids for tolerance to coconut foliar decay disease in Vanuatu, South Pacific
}

Jean-Pierre Labouisse*, CIRAD, UMR DAP, F-34398 Montpellier, France

Tiata Sileye, VARTC, PO Box 231, Santo, Vanuatu

François Bonnot, CIRAD, UPR Étiologie dépérissements, F-34398 Montpellier, France

Luc Baudouin, CIRAD, UPR Étiologie dépérissements, F-34398 Montpellier, France

*corresponding author: labouisse@ cirad.fr; Phone: +33 46761 75 78; Fax: +334676157

93

\begin{abstract}
Coconut foliar decay (CFD) is a disease of coconut (Cocos nucifera L.) associated with infection by coconut foliar decay virus (CFDV), which is endemic in Vanuatu, South Pacific. The local cultivar 'Vanuatu Tall' (VTT) is the only cultivar that is fully tolerant to CFD, whereas introduced cultivars and hybrids are affected to different degrees. From 1967 to 2008 a conventional breeding programme was conducted with the aim of creating hybrid planting material combining tolerance to CFD with improved copra yield and high copra weight per nut. This objective was achieved by crossing the progeny of selfed trees of 'Rennell Island Tall' (RIT) cultivar, selected for their low susceptibility to CFD in field screening tests, with VTT, improved by mass selection and intercrossing. An improved VTT x RIT hybrid was identified with a high degree of tolerance to CFD (less than $1 \%$ of diseased trees after 11 years of exposure to high disease pressure). The annual production of the improved VTT $\mathrm{x}$ RIT hybrid ranged from 21.9 to $28.6 \mathrm{~kg}$ of copra per tree, depending on the RIT parent, and was, on average, 34\% higher than that of 'VTT Elite' an advanced cultivar obtained after four selection cycles of local VTT. However, the production of the hybrid in Vanuatu involves constraints such as frequent replanting and isolation of the seed garden and CFD control for the RIT parents. The importance of conducting research on the genetic determinism and the mechanism of tolerance to CFD for better control of the disease in the event that it spreads outside Vanuatu is discussed.
\end{abstract}


Keywords Breeding, Cocos nucifera, Coconut, Hybrid, Pacific, Plant viruses, Virus tolerance, Vanuatu

$\begin{array}{ll}\text { Abbreviations } \\ \text { CFD } & \text { Coconut foliar decay } \\ \text { CFDV } & \text { Coconut foliar decay virus } \\ \text { CLY } & \text { Coconut lethal yellowing } \\ \text { MRD } & \text { Malayan Red Dwarf } \\ \text { MVT } & \text { Markham Valley Tall } \\ \text { RIT } & \text { Rennell Island Tall } \\ \text { SIT } & \text { Solomon Islands Tall } \\ \text { VRD } & \text { Vanuatu Red Dwarf } \\ \text { VTT } & \text { Vanuatu Tall }\end{array}$

\section{Introduction}

The Republic of Vanuatu is an archipelago made up of 80 islands and islets straddling the 13th and 22nd parallels in the south-western Pacific Ocean, between the Solomon Islands and the Republic of Fiji Islands. According to the 2007 agricultural census, $70 \%$ of rural households grow coconut palms (Vanuatu National Statistics Office 2008). In Vanuatu, copra, which is the dried fruit endosperm, has been the most important export commodity and the mainstay of the economy since the beginning of the 20th century (Weightman 1989). In 2008, copra and coconut oil still accounted for $50.6 \%$ of export earnings (Vanuatu National Statistics Office 2009).

In 1962, a French research organization, the Institut de Recherches pour les Huiles et Oléagineux (IRHO) set up an agricultural centre dedicated to coconut research and development near the village of Saraoutou on the island of Espiritu Santo. The main objective of the research was to increase copra production through modern cultivation practices and the use of improved planting material. Since the creation of first known coconut hybrids by Marechal in Fiji in 1926, many breeding programmes in the world have been based on hybridization between cultivars of different origins and have led to considerable increases in copra yield (Batugal et al. 2009). Traditionally, coconut cultivars are categorised as 'Talls' or 
'Dwarfs' according to their growth characteristics and mating behaviour. Whereas most Dwarfs are homozygous and self-pollinated, Talls are heterozygous and predominantly crosspollinated. The most common types of hybrids are single crosses between Dwarf and Tall cultivars, and between unrelated Tall cultivars (Perera et al. 2009).

In Vanuatu, IRHO researchers decided to develop high-yielding hybrids to replace ageing coconut plantations. In 1964 they started a collection by importing coconut cultivars originating from other countries. Eighteen months after the first introductions, a previously unseen wilt, later called coconut foliar decay or CFD, appeared in 'Rennell Island Tall' (RIT) and several dwarf cultivars. Symptoms of the disease were described by Calvez et al. (1980) in 'Malayan Red Dwarf' (MRD), the most susceptible cultivar with up to $90 \%$ mortality observed after 7 years in the field. Yellowing of the leaflets starts on the middle fronds of the crown, followed by lateral necrosis of the stalks. Fronds gradually turn brown then dry, and stalks break prematurely (Fig. 1). At a later stage, yellowing extends to the upper fronds. The inflorescences are also affected and the young nuts turn brown and fall. Death occurs one to two years after the first symptoms appear. In the case of more tolerant cultivars, remission may be observed in a percentage of affected trees and, after recovery, these trees become disease tolerant, but their yield is significantly reduced for a few years. The percentage of affected trees and of recovered trees varies with the cultivar and cultivation conditions.

Fig. 1 First symptoms of CFD in a 'Malayan Red Dwarf' cultivar. Saraoutou research station, Vanuatu (photo J.P. Labouisse, 2001)

Julia (1982) found that the disease is transmitted by a specific plant-hopper vector Myndus taffini Bonfils (Cixiidae), which breeds on the roots of burao (Hibiscus tiliaceus L.), a tree commonly found on Pacific seashores, and which feeds on coconut leaves. A small circular single-stranded DNA virus was identified as the putative causal agent by Randles et al. (1986) and named coconut foliar decay virus (CFDV). The local coconut 'Vanuatu Tall' (VTT) is the only cultivar that neither expressed symptoms nor succumbed to the disease although it can be infected with CFDV (Randles et al. 1992). Consequently, VTT can be considered as

\footnotetext{
${ }^{1}$ Also called 'New Hebrides Tall' (NHT) before the country became independent (1980); in French, 'Grand Nouvelles-Hébrides' (GNH) then 'Grand du Vanuatu' (GVT); in Portuguese, 'Gigante de Vanuatu' then 'Gigante de Novas Hebridas'. VTT is the international abbreviation for Vanuatu Tall.
} 
fully tolerant rather than as resistant to CFD, and local plantations can constitute a large latent reservoir of virus for susceptible cultivars (Hanold et al. 1988).

Once the nature of the decay was established and varietal tolerance observed, the objective of the breeding programme was to develop high yielding cultivars that are naturally tolerant to CFD. Coconut breeding in Vanuatu thus proceeded along two parallel and complementary lines. The first was to improve VTT by mass selection and inter-crossing, which resulted in the cultivar 'Vanuatu Tall Elite' (Labouisse et al. 2004). The second line was a major hybridization programme which led to the creation of 60 different hybrids between 1967 and 2003, among which 13 had VTT as a parent (Labouisse et al. 2005). Almost all the hybrids showed varying degrees of susceptibility to CFD. Only two hybrids showed good tolerance to the disease and were significantly more productive than 'Vanuatu Tall': 'Vanuatu Red Dwarf' x 'Vanuatu Tall' (VRD x VTT) and 'Vanuatu Tall' x 'Rennell Island Tall' (VTT x RIT). The VRD x VTT hybrid exhibited disadvantages including premature nut fall, high susceptibility to strong winds, and low copra weight per nut, and so its distribution was stopped in 1996. Research then concentrated on improving the VTT x RIT hybrid for tolerance to CFD, as this was shown to be incomplete when the trees were exposed to high disease pressure.

In coconut, there are few examples of genetic crossings aimed at both improved yield and tolerance to disease. The most remarkable are the hybrids developed in Ghana and tested in screening trials for tolerance to Cape St Paul Wilt disease, the Ghanaian form of coconut lethal yellowing (CLY), which is a group of diseases caused by a phytoplasma. The hybrid 'Sri Lanka Green Dwarf x Vanuatu Tall', and, to a lesser extent, the hybrid 'Malayan Yellow Dwarf x Vanuatu Tall' have been shown to be more resistant than hybrids of the local cultivar 'West African Tall' (Dery et al. 2008). In the Ghanaian experiments, VTT and RIT were the least affected of Tall cultivars, whereas, in Jamaica, VTT was found to be highly susceptible to the Caribbean form of CLY (Been 1981). Such a difference in susceptibility may reflect variability of the pathogen strains (Dollet et al. 2009).

In Vanuatu, Calvez et al. (1980) reported preliminary results of the first experiment on VTT $x$ RIT hybrids conducted in the 1970s at Saraoutou research station, now called Vanuatu Agricultural Research and Technical Centre (VARTC). We present the results of this first experiment, and the subsequent steps in the breeding programme for increasing the tolerance of VTT x RIT to CFD. This programme has continued for a period of 42 years ending in 2008 
with a comparative assessment of the agronomic performance of the improved VTT x RIT and of 'VTT Elite'. Finally, we examine the conditions of production of hybrids in Vanuatu, and discuss the importance of conducting research on the genetic determinism and the mechanism of tolerance to CFD for better control of the disease, particularly in the event that it spreads outside Vanuatu.

\section{Material and methods}

\section{Trial site}

The breeding programme was conducted at Saraoutou research station $\left(15^{\circ} 27^{\prime} \mathrm{S}, 167^{\circ} 12^{\prime} \mathrm{E}\right)$, located $11 \mathrm{~km}$ north of the city of Luganville on the east coast of the island of Espiritu Santo. The experimental station extends over 500 hectares both on a low terrace along the coast with shallow humus-bearing coral soils and on a limestone plateau enriched with volcanic ash, with deep, fertile soils rich in clay and organic matter. The site has a warm wet tropical climate with abundant rainfall (an average of 2,861 mm between 1986 and 2008) and average monthly temperatures between $21.6^{\circ} \mathrm{C}$ and $28.6^{\circ} \mathrm{C}$.

\section{The parent cultivar 'Vanuatu Tall'}

The term 'Vanuatu Tall' refers to the indigenous germplasm conserved at Saraoutou station. It comprises two coconut populations collected in the 1960's from two large plantations on the island of Espiritu Santo, namely 'Surunda' and 'Leroux', and their progeny. The stages of the VTT breeding programme are described in detail by Labouisse et al. (2004) and are summarized in Fig. 2. Selection led to an increase in the average weight of copra per nut, from $139.2 \pm 28.5^{2} \mathrm{~g}$ in the 'Leroux' plantation (VTT generation G0) to over $200 \mathrm{~g}$ for the improved VTT (generations G2 and G3).

Fig. 2 Steps in the breeding programme of 'Vanuatu Tall' coconut at Saraoutou station. Dates of field planting are in brackets. From Labouisse et al. (2004)

\section{The parent cultivar 'Rennell Island Tall'}

'Rennell Island Tall' (RIT) originates from Rennell, a coral island located $200 \mathrm{~km}$ south of Guadalcanal in the Solomon Islands. RIT has large nuts with high copra content (Whitehead

\footnotetext{
${ }^{2}$ Mean \pm standard deviation
} 
1966). Foale (1964) recorded weights varying from 1780 to $2760 \mathrm{~g}$ for the fresh nuts and from 265 to $404 \mathrm{~g}$ for the copra per nut on Rennell Island. De Nucé and Wuidard (1981) recorded an average dry nut weight of $1692 \pm 304 \mathrm{~g}$ and a copra weight per nut of $309 \pm 34 \mathrm{~g}$ at Marc Delorme station in Côte d'Ivoire. The annual production of an adult tree varies from 48 to 75 nuts (Bourdeix 1993). RIT has been successfully used in crossing with 'West African Tall' (WAT) in Côte d'Ivoire (Bourdeix 1991) and with MRD in the Pacific (Foale 1987). RIT was classified as very susceptible to CFD by Julia (1985) but showed a significant proportion of cases of remission. In the collection plot FG-1 at Saraoutou, 16 years after planting, $86.0 \%$ of RIT trees were affected out of a total of 286 , and $55.6 \%$ died, meaning that $35.3 \%$ of diseased trees recovered spontaneously (De Nucé and Wuidart 1981).

\section{Methods of crossing}

Hybrids were created by hand pollination (Santos et al. 1996). Inflorescences were emasculated by removing all male flowers from trees used as female parents. Then these inflorescences were bagged and, when the stigmas of the female flowers were receptive, the selected pollen was introduced into the bags. Coconut has a low reproduction rate; under natural pollination, it is often below 100 nuts a year. Hand pollination reduces that rate to 30 nuts per tree. After harvest, the hybrid nuts were sown in the nursery, with a culling rate of 20 to $30 \%$, thus reducing the reproduction rate to about 20 hybrid seedlings per tree. Around 20 months were required between pollination and the establishment of the hybrid seedlings in the field, including a period of 8 months in the nursery.

Fifteen years after planting in the field, the inflorescences of Tall coconuts become difficult to access and the trees have to be replaced for use as parental material. Self-pollination was adopted to reproduce RIT trees that were not affected by CFD. Because of the heterozygotic characteristics of their genomes, this method results in an increase in the frequency of homozygotic loci and inbreeding depression.

\section{Field screening tests (ST) for CFD tolerance}

Tolerance to CFD was assessed in the field by planting trees in plots exposed to high disease pressure. This was achieved by planting near Hibiscus tiliaceus, so as to maintain a high density of the vector Myndus taffini. In the screening tests, the level of disease pressure was checked by interplanting trees with the very susceptible MRD cultivar. According to Julia et al. (1985), at least four years' exposure to CFDV in the field is necessary to judge whether an 
unaffected cultivar of coconut is likely to prove highly tolerant if the susceptible MRD control is affected.

\section{Cultivar trials $(C T)$}

The yield characteristics of the tested varieties were recorded using COGENT standardized methods (Santos et al. 1996). Seedlings were planted following a randomized complete block design at a density of 143 trees per hectare with a spacing of 9 metres in a triangular arrangement. For precocious cultivars like VTT and VTT x RIT, the juvenile period ends between four and five years after planting. The assessment of the production potential required recording for at least four harvesting years, i.e. from nine to 10 years after planting, in the absence of hazards such as cyclones, or severe attacks of pests or fungi. The yield of a coconut tree depends on two parameters: the number of nuts per tree and the copra weight per nut. A high copra weight per nut is a particularly desirable trait because, in the copra process, it facilitates endosperm removal before drying and decreases labour requirements. At Saraoutou, the yields were estimated by recording the number of ripe nuts, tree by tree, at a rate of six harvesting rounds per year. The components of the nut were then determined by sampling the experimental plots to make up a sample of 10 to 20 nuts per treatment. Copra weight was calculated from the weight of fresh endosperm, and the moisture content of the endosperm was obtained after drying a sample piece weighing about $20 \mathrm{~g}$ in an oven at $105^{\circ} \mathrm{C}$. By definition, copra weight is equivalent to that of endosperm with $6 \%$ moisture. The copra yield per tree is thus equal to the number of nuts multiplied by the weight of copra per nut.

\section{Cultivar development step by step}

The development of a VTT x RIT cultivar with improved productivity and CFD tolerance extended over a period of 42 years between 1967 and 2008. The planting material, experimental conditions, and the main characteristics of the field experiments are summarized in Table 1. 
Table 1 Main characteristics of the experimental fields at Saraoutou station cited in the article.

\begin{tabular}{|c|c|c|c|c|}
\hline $\begin{array}{c}\text { Field } \\
\text { number }\end{array}$ & Cultivars & $\begin{array}{l}\text { Planting } \\
\text { date } \\
\text { (Plot } \\
\text { number) }\end{array}$ & Experimental design & $\begin{array}{c}\text { CFD } \\
\text { pressure }\end{array}$ \\
\hline FG-1 & $\begin{array}{l}\text {-RIT (origin: Rennell Is.) } \\
\text {-MRD } \\
\text {-VTT1 }(\mathrm{G} 1)^{\mathrm{a}}\end{array}$ & $\begin{array}{l}1964 \\
(\mathrm{P} 02)\end{array}$ & $\begin{array}{l}\text { No experimental design } \\
\text { RIT ( } 286 \text { trees) } \\
\text { MRD (212) } \\
\text { VTT (416) }\end{array}$ & High \\
\hline FG-2 & -RIT (origin: FG-1) & $\begin{array}{c}1970 \\
(\mathrm{P} 00)\end{array}$ & $\begin{array}{l}\text { No experimental design } \\
\text { RIT ( } 156 \text { trees) }\end{array}$ & High \\
\hline CT-1 & $\begin{array}{l}\text {-VTT2 (G1) as a control } \\
\text {-VTT (G0) x RIT (origin: Rennell Is.) } \\
\text {-VTT (G0) x SIT (origin: Solomon Is.) } \\
\text {-RIT (origin: FG-1) } \\
\text {-RIT x SIT (origin: Solomon Is.) } \\
\text {-MRD x VTT (G0) } \\
\text {-MVT (origin : Papua New Guinea) }\end{array}$ & $\begin{array}{l}1969 \\
(\mathrm{P} 43)\end{array}$ & $\begin{array}{l}\mathrm{RCB}, 8 \text { blocks, } 18 \\
\text { trees/experimental plot }\end{array}$ & Medium \\
\hline CT-2 & $\begin{array}{l}\text {-VTT Elite (G4) as a control } \\
-15 \text { crosses VTT (G2) x RIT } \\
\text { ( } 3 \text { half-sib families, } 5 \text { trees/family) }\end{array}$ & $\begin{array}{l}1998 \\
(\mathrm{P} 50)\end{array}$ & $\begin{array}{l}\mathrm{RCB}, 4 \text { blocks, } 12 \\
\text { trees/experimental plot }\end{array}$ & Medium \\
\hline ST-1 & -VTT (G0) x RIT (origin: FG-1) & $\begin{array}{l}1970 \\
(\mathrm{P} 02)\end{array}$ & $\begin{array}{l}\text { No experimental design } \\
\text { Same location as FG-1 } \\
\text { VTT x RIT ( } 61 \text { trees) }\end{array}$ & High \\
\hline ST-2 & $\begin{array}{l}\text {-RIT (18 selfed families of RIT originated } \\
\text { from FG-1 and FG-2) } \\
\text {-MRD }\end{array}$ & $\begin{array}{l}1980 \\
(\mathrm{E} 02)\end{array}$ & $\begin{array}{l}\text { Rows of RIT trees (on } \\
\text { average } 20 \text { trees/family) } \\
\text { with interplanted MRD }\end{array}$ & High \\
\hline ST-3 & $\begin{array}{l}-15 \text { crosses VTT (G2) x RIT } \\
\text { ( } 3 \text { half-sib families, } 5 \text { trees/family) } \\
\text {-MRD }\end{array}$ & $\begin{array}{l}1998 \\
(\mathrm{E} 03)\end{array}$ & $\begin{array}{l}\text { On average } 11 \text { trees ( } 3 \\
\text { to } 4 \text { sets of } 3 \text { trees) with } \\
\text { interplanted MRD }\end{array}$ & High \\
\hline
\end{tabular}

- Initial assessment of VTT x RIT hybrid (cultivar trial CT-1 and screening test ST1) The first VTT x RIT hybrid was created in 1967 by pollinating VTT 'Leroux' (Generation G0) with RIT pollen imported from Lever's Pacific Plantations located on Russell Islands, the Solomon Islands. The hybrid was observed and compared with other cultivars and both parents in cultivar trial CT-1, in a field moderately exposed to CFD pressure. In 1970, 61 other VTT x RIT trees produced by crossing VTT1 (Generation G1) and RIT of the FG-1 collection, were planted in the screening test ST-1 under CFD high pressure.

- Improvement of the tolerance of VTT x RIT hybrid

It was assumed that individual trees of the RIT cultivar that had never expressed any symptom of CFD when exposed over a long period to high disease pressure would have a genotype rendering them highly tolerant to CFD. To find tolerant RIT genotypes, 18 RIT trees that had never been affected by CFD were chosen from the FG-1 and FG-2 collections and selfpollinated. The progeny of each of these 18 selfed trees were planted in the ST-2 screening 
test under high CFD pressure and observed over a period of 13 years. The most tolerant of these selfed families were selected and then crossed with improved VTT (Generation G2) to create hybrids, which were assessed for CFD tolerance in the ST-3 screening test and for yield in the CT-2 trial. The trees of these tolerant selfed families were again self-pollinated to maintain their genetic inheritance, so that, once their combining ability was estimated, they could be used as the male parent for the large-scale production of hybrid seeds (Fig. 3).

Fig. 3 Steps in the production of VTT x RIT hybrids with improved CFD tolerance at Saraoutou station

\section{Statistical analyses}

Graphics and statistical analyses were performed with the statistical software package $R$, version 2.8.0. (R Development Core Team 2009). Analyses of variance, comparisons of means, chi-square test, and exact binomial confidence intervals were computed with the $R$ Stats package. When appropriate, the differences between cultivars for each trait were analysed by Tukey's honest significant difference test (Miller 1981).

\section{Results}

\section{Cultivar trial CT-1}

In trial CT-1, VTT x RIT trees moderately exposed to CFD showed a much better tolerance than 'Markham Valley Tall' (MVT), the most susceptible cultivar in the trial, RIT, and other hybrids (Fig. 4). Whereas the first symptoms of the disease appeared in MVT four years after planting, the first symptoms only appeared in three VTT $x$ RIT trees in the $12^{\text {th }}$ year and in two other trees the following year. During the $13^{\text {th }}$ year, the symptoms in the first three diseased trees began to recede and the trees started to recover. For the parent cultivar RIT, $58.5 \%$ of the trees were affected after 13 years in the field, but $27.6 \%$ of them recovered. The VTT x RIT hybrid produced significantly more copra than either parent (Table 2). Because of a higher tolerance to CFD, it was also more productive in the long term than all the other tested hybrids (data not shown). The weight of the copra per nut of the hybrid was close to the mean weight of both parents' copra per nut.

Fig. 4 Trial CT-1. Progress in the percentage of coconut trees affected by CFD. On the right, codes of cultivars with the cumulated percentage of affected trees 13 years after planting (recovered trees not deducted) 
Table 2 Trial CT-1. Average annual values of yield components over the period from year 5 to year 10 after planting

\begin{tabular}{lcrcc}
\hline \multicolumn{1}{c}{ Cultivar } & $\begin{array}{c}\text { Number of } \\
\text { nuts/tree }\end{array}$ & $\begin{array}{c}\text { Copra/nut } \\
(\mathrm{g})\end{array}$ & $\begin{array}{c}\text { Copra/tree } \\
(\mathrm{kg})\end{array}$ & $\begin{array}{c}\text { Copra/hectare } \\
(\mathrm{t})\end{array}$ \\
\hline RIT & $36.6 \mathrm{a}$ & $293.7 \mathrm{c}$ & $10.1 \mathrm{a}$ & 1.44 \\
VTT2 (G1) & $84.3 \mathrm{~b}$ & $179.9 \mathrm{a}$ & $14.7 \mathrm{~b}$ & 2.10 \\
VTT x RIT & $86.0 \mathrm{~b}$ & $223.5 \mathrm{~b}$ & $18.2 \mathrm{c}$ & 2.60 \\
\hline Standard error & 2.6 & 4.3 & 0.5 & 0.07 \\
\hline${ }^{a}$ Yield calculated on the basis of 143 trees per hectare & & & \\
For each column, different letters indicate significant differences according to Tukey's honest significant difference test $(P \leq$ \\
0.05)
\end{tabular}

\section{Screening trial ST-1}

In screening test ST-1, VTT x RIT trees under high disease pressure displayed a rather high morbidity rate. Ten years after planting, while $100 \%$ of MRD had died from CFD, a total of 15 VTT x RIT trees (i.e. $24.6 \%$ of the trees) were affected and eight of them recovered spontaneously.

\section{RIT selfed families in screening test ST-2}

At 16 months after planting, 79.5\% of MRD were affected, which confirmed the high level of disease pressure. After 13 years, out of a total of 355 RIT trees under observation, 54.4\% were affected by CFD and $16.9 \%$ died. However Table 3 shows that the percentage of affected trees varied according to the selfed RIT parent, ranging from 11.5\% (VT131 family) to $95.8 \%$ (VT143 family). 
Table 3 Screening test ST-2. Number of trees affected or killed by CFD among 18 RIT selfed families over a period of 13 years after planting (1980-1992)

\begin{tabular}{cccc}
\hline RIT selfed family & $\begin{array}{c}\text { Total number of } \\
\text { trees observed }\end{array}$ & $\begin{array}{c}\text { Trees affected } \\
\text { by CFD }\end{array}$ & $\begin{array}{c}\text { Trees killed } \\
\text { by CFD }\end{array}$ \\
\hline VT128 & 26 & 19 & 2 \\
VT129 & 24 & 12 & 0 \\
VT130 & 23 & 14 & 2 \\
VT131 & 26 & 3 & 0 \\
VT132 & 23 & 4 & 1 \\
VT133 & 13 & 6 & 1 \\
VT134 & 23 & 12 & 6 \\
VT135 & 24 & 4 & 0 \\
VT136 & 8 & 7 & 3 \\
VT137 & 24 & 16 & 13 \\
VT138 & 11 & 9 & 6 \\
VT139 & 10 & 5 & 4 \\
VT140 & 26 & 12 & 1 \\
VT141 & 18 & 15 & 4 \\
VT142 & 12 & 10 & 6 \\
VT143 & 24 & 23 & 6 \\
VT144 & 24 & 12 & 1 \\
VT145 & 16 & 10 & 4 \\
\hline TOTAL & 355 & 193 & 60 \\
\hline$\chi^{2}$ & $-v$ & 86.81 & - \\
p-value $(\alpha=0.05)$ & - & 0.0001 & - \\
\hline
\end{tabular}

${ }^{\text {a }}$ p-value computed by Monte Carlo simulation with 5000 replicates

The chi-square contingency table test for independence $(\alpha=0.05)$ shows that the proportions of trees affected by CFD differed among selfed families (Table 3). The exact binomial confidence intervals of the proportions of trees affected by CFD show that three families were significantly below the mean (Fig. 5). We selected these three families: VT131, VT132, and VT135 with 3/26, 4/23, and 4/24 trees affected by CFD, and 0/26, 1/23, and 0/24 trees killed by CFD respectively. Among each of them, five unaffected productive trees were selected and used to pollinate improved VTT. The progeny of the 15 crosses (numbered from VT195 to VT209) were assessed for CFD tolerance in the screening test ST-3 and for yield in the trial CT-2.

Fig. 5 Screening test ST2. The 18 RIT selfed families are ordered by increasing proportion of diseased trees. The error bars represent the exact binomial confidence intervals at level 0.05 . The dashed line represents the overall proportion of diseased trees. Selected families are indicated by an asterisk. 
Improved VTT $x$ RIT in screening test ST-3

In 2009, 11 years after planting the trees in a field exposed to high disease pressure, we recorded only one case of CFD (and no case of death) among the 162 trees representing the progeny of the 15 VTT x RIT crosses. The diseased tree belonged to the hybrid progeny VT199 (RIT parental family VT131).

\section{Improved VTT $x$ RIT in cultivar trial CT-2}

Three years after planting, $75 \%$ of the hybrids bore flowers as opposed to $56 \%$ for 'VTT Elite'. For the yield components, we analyzed the data from two aspects. In the first analysis, we compared 16 levels of treatment: 15 VTT x RIT crosses and 'VTT Elite'. In the second analysis, we grouped the hybrids into families according to the selfed RIT parent, and compared four levels of treatment: three half-sib families and 'VTT Elite'. Contrast analysis (Table 4) shows that, for the production of copra per tree, there was no significant difference among VTT x RIT crosses within families, but there was a significant difference between the three families, and between the families and 'VTT Elite'. Concerning copra per nut, there was no significant difference between hybrids and 'VTT Elite'. The difference in yield between 'VTT Elite' and hybrids was mainly determined by the number of nuts. The results of the first analysis (Table 5, section A) show that, on average, the hybrids produced more nuts $(+28.1 \%)$, with a higher copra weight per nut $(+4.9 \%)$, and were more productive $(+33.9 \%)$ than 'VTT Elite'. The VT135 family had the best yield (3.83 t copra/hectare), significantly higher than that of VT132 family (Fig. 6). Difference in yield between families was also determined by the number of nuts and not by the copra weight per nut (Table 5, section B). After 11 years, no case of CFD was recorded in trial CT-2, in which the trees were exposed to moderate disease pressure. 
Table 4 Trial CT-2. Analysis of variance of yield components for the 15 VTT x RIT crosses grouped by family and 'VTT Elite' (control) for the period from year 5 to year 8 after planting

\begin{tabular}{|c|c|c|c|c|}
\hline \multirow[b]{2}{*}{ S.V. } & \multirow[b]{2}{*}{ Df } & \multicolumn{3}{|c|}{ Mean squares } \\
\hline & & Number of nuts/tree & Copra/nut & Copra/tree \\
\hline Blocks & 3 & $441.2 *$ & $349.2 *$ & 6.5 \\
\hline Cultivar & 3 & $1614.5^{* * *}$ & $494.8 * *$ & $59.8 * * *$ \\
\hline - Family & (2) & $1259.3 * * *$ & $618.2 * *$ & $20.2 *$ \\
\hline -VTT vs Family & (1) & $2324.7 * * *$ & 248.0 & $139.1 * * *$ \\
\hline $\mathrm{H}^{\mathrm{a}}$ within Family & 12 & $326.4^{*}$ & $783.1 * * *$ & 7.68 \\
\hline Error & 45 & 137.7 & 105.7 & 5.79 \\
\hline Total & 63 & & & \\
\hline
\end{tabular}

Table 5 Trial CT-2. Average annual values of yield components calculated from year 5 to year 8 after planting for 15 VTT x RIT crosses taken separately (A) or grouped by family (B), and VTT Elite (control)

\begin{tabular}{|c|c|c|c|c|c|}
\hline Treatment & Family & $\begin{array}{c}\text { Number of } \\
\text { nuts/tree }\end{array}$ & $\begin{array}{c}\text { Copra/nut } \\
(\mathrm{g})\end{array}$ & $\begin{array}{c}\text { Copra/tree } \\
(\mathrm{kg})\end{array}$ & $\begin{array}{c}\text { Copra/hectare } \\
\text { (t) }\end{array}$ \\
\hline \multicolumn{6}{|c|}{ A- VTT x RIT crosses } \\
\hline VT209 & VT135 & $142.5 \mathrm{a}$ & $200.3 \mathrm{~d}$ & 28.6 a & 4.09 \\
\hline VT195 & VT131 & $129.8 \mathrm{abc}$ & $213.3 \mathrm{bcd}$ & $27.7 \mathrm{a}$ & 3.96 \\
\hline VT208 & VT135 & $137.6 \mathrm{ab}$ & $198.5 \mathrm{~d}$ & $27.1 \mathrm{a}$ & 3.88 \\
\hline VT205 & VT135 & $119.6 \mathrm{abcd}$ & 223.7 abcd & $26.7 \mathrm{a}$ & 3.82 \\
\hline VT207 & VT135 & $115.5 \mathrm{abcd}$ & $231.3 \mathrm{ab}$ & 26.6 a & 3.80 \\
\hline VT199 & VT131 & $108.8 \mathrm{bcd}$ & $241.7 \mathrm{a}$ & $26.3 \mathrm{a}$ & 3.76 \\
\hline VT204 & VT132 & $112.3 \mathrm{bcd}$ & $230.4 \mathrm{ab}$ & $25.8 \mathrm{ab}$ & 3.69 \\
\hline VT203 & VT132 & $121.8 \mathrm{abcd}$ & $211.8 \mathrm{bcd}$ & $25.8 \mathrm{ab}$ & 3.69 \\
\hline VT201 & VT132 & 109.6 bcd & $232.2 \mathrm{ab}$ & $25.4 \mathrm{ab}$ & 3.64 \\
\hline VT196 & VT131 & $114.0 \mathrm{abcd}$ & $222.3 \mathrm{abcd}$ & $25.3 \mathrm{ab}$ & 3.62 \\
\hline VT197 & VT131 & $123.7 \mathrm{abcd}$ & $204.0 \mathrm{~cd}$ & $25.2 \mathrm{ab}$ & 3.60 \\
\hline VT198 & VT131 & $121.6 \mathrm{abcd}$ & $206.6 \mathrm{bcd}$ & $25.1 \mathrm{ab}$ & 3.59 \\
\hline VT202 & VT132 & $109.9 \mathrm{bcd}$ & $228.0 \mathrm{abc}$ & $24.9 \mathrm{ab}$ & 3.56 \\
\hline VT206 & VT135 & $123.0 \mathrm{abcd}$ & $201.8 \mathrm{~cd}$ & $24.8 \mathrm{ab}$ & 3.55 \\
\hline VT200 & VT132 & $105.1 \mathrm{~cd}$ & $208.6 \mathrm{bcd}$ & $21.9 \mathrm{~b}$ & 3.13 \\
\hline VTT Elite & - & $94.7 \mathrm{~d}$ & $208.8 \mathrm{bcd}$ & $19.7 \mathrm{~b}$ & 2.82 \\
\hline \multicolumn{6}{|c|}{ B- VTT x RIT crosses grouped by family } \\
\hline VT135 family & & $127.6 \mathrm{~A}$ & $211.1 \mathrm{~B}$ & $26.8 \mathrm{~A}$ & 3.83 \\
\hline VT131 family & & $119.6 \mathrm{AB}$ & $217.6 \mathrm{AB}$ & $25.9 \mathrm{AB}$ & 3.70 \\
\hline VT132 family & & $111.7 \mathrm{~B}$ & $222.2 \mathrm{~A}$ & $24.8 \mathrm{~B}$ & 3.55 \\
\hline VTT Elite & & $94.7 \mathrm{C}$ & $208.8 \mathrm{~B}$ & $19.7 \mathrm{C}$ & 2.82 \\
\hline
\end{tabular}

Fig. 6 Trial CT-2. Production of copra per tree of hybrids grouped by family and 'VTT Elite' (control). Each circle represents the value of one experimental plot. The mean values of the families are represented by horizontal bars. The error bars represent the standard error. 


\section{Discussion}

The general goal of the breeding programme in Vanuatu was to create planting material adapted to the agro-ecological conditions of the country, which combined tolerance to CFD with improved yield and high copra weight per nut. This goal was achieved by crossing the progeny of selfed trees of RIT cultivar, selected in screening tests for their low susceptibility to CFD, with VTT improved by mass selection and intercrossing.

\section{Tolerance of the VTT $x$ RIT hybrid to CFD}

From the very first hybrid trial (CT-1) RIT was found to be the best candidate for crossing with VTT for CFD tolerance, based on the following criteria: (i) a long period -11 years - of exposure to the disease required before the first symptoms appear, compared to less than two years for the very susceptible MRD and less than six years for the other susceptible cultivars; (ii) a low proportion of diseased trees (3.6\%); and (iii) a high percentage of recovery (60\%). By selecting and selfing RIT parents that withstood CFD in FG-1 and FG-2 we improved the degree of tolerance of their progeny with an average rate of $54.4 \%$ of diseased trees and $16.9 \%$ of dead trees in screening test ST-2 compared to $86.0 \%$ and $55.6 \%$ respectively in FG1. The trees of the most tolerant selfed families (VT131, VT132, and VT135) selected in ST2, after crossing with VTT, provided hybrids with less than $1 \%$ of trees affected by CFD after 11 years of exposure to high disease pressure in screening test ST-3. Therefore, the improved VTT x RIT can be considered as highly tolerant compared to the first VTT x RIT hybrids exposed to similar conditions in screening test ST-1 where $24.6 \%$ of the trees were diseased.

\section{Yield of VTT Elite and of the VTT $x$ RIT hybrid}

Comparison of the results of CT-1 and CT-2 cultivar trials showed that the copra yield of the VTT cultivar improved: $19.7 \mathrm{~kg} /$ tree (i.e. 2.8 tonnes/hectare) for 'VTT Elite' (generation G4) compared to $14.7 \mathrm{~kg} /$ tree (2.1 tonnes/ha) for VTT1 (generation G1), mainly by increasing copra weight per nut (209 $\mathrm{g}$ and $180 \mathrm{~g}$ respectively). In both trials the VTT x RIT hybrid was significantly more productive than VTT (+24\% in CT-1 and $+34 \%$ in CT -2$)$. In CT-2, the best hybrid (VT209) of the best family (VT135) reached $28.6 \mathrm{~kg} / \mathrm{tree}$ i.e. 4.1 tonnes/hectare. In Côte d'Ivoire, Bourdeix (1991) reported similar yields obtained with 'West African Tall' x 'Rennell Island Tall' ( $31.4 \mathrm{~kg} /$ tree i.e. 4.5 tonnes/hectare), which is the most productive Tall $\mathrm{x}$ Tall hybrid ever tested in Côte d'Ivoire, and with 'Polynesian Tall' x 'Rennell Island Tall' (27.1 kg/tree i.e. 3.9 tonnes/hectare). Bourdeix (1989) also observed that RIT had a high 
genetic combining ability for both yield components (number of nuts and copra weight per nut).

\section{Constraints to the production of hybrids in Vanuatu}

At first sight the improved VTT x RIT hybrid, which is precocious, highly productive and tolerant to CFD, should be preferred as new planting material. However, the constraints that hamper the production of this hybrid in Vanuatu should not be underestimated. First, a seed garden of Tall coconuts has an economic lifespan of about 10 years and thus has to be replanted to ensure that inflorescences of VTT continue to be accessible for emasculation and pollination. Second, the maintenance of the RIT parents used as pollinators can be difficult because of their limited tolerance to CFD, even if uprooting Hibiscus tiliaceus groves within a radius of several hundred metres around coconuts has proved to be relatively efficient in controlling the spread of the disease (Hanold et al. 2003). As a practical consequence, such seedgardens can only be established in a limited number of locations such as agricultural stations with skilled staff to run them. These constraints have to be compared to the ease of production of 'VTT Elite', which can be done in seedgardens established anywhere in the country (including on-farm locations) and exploited in open pollination for at least 50 years. Vanuatu has a scattered coconut grove of about 10 million trees, of which $18 \%$ are more than 50 years old (Vanuatu National Statistics Office 2008) and are due to be replaced. Vanuatu has limited means to set up seedgardens and transport seeds and seedlings across the islands. Consequently, the VTT x RIT hybrids that are now produced at Saraoutou station should be considered as a complement to mass production of 'VTT Elite'.

\section{Further research on the disease}

The cause, vector, and disease cycle of CFD were determined in less than 10 years (Hanold et al. 2003), thanks to close collaboration between entomologists, virologists and breeders of the Waite Agricultural Research Institute of the University of Adelaide and the Institut de Recherches pour les Huiles et Oléagineux, integrated in 1984 into the Centre de Coopération Internationale en Recherche Agronomique pour le Développement (CIRAD), and the financial support of the Australian Centre for International Agricultural Research. Various methods of CFD diagnosis by analysing CFDV DNA were developed, and a protocol based on a unilateral polymerase chain reaction is available for routine indexing (Randles et al. 1999). However, studies related to the virus were stopped in 1993, even though many 
questions concerning the mechanism and the genetic determinism of CFD tolerance remain unanswered.

Coconut foliar decay can be described as an orphan disease, which is of no economic importance at the present time because it is limited to Vanuatu, and has no particular impact in this country because of the complete tolerance of the local cultivar. Until now, CFD has not been reported outside Vanuatu and, although other species of the genus Myndus have been identified in neighbouring Pacific countries (Wilson 1988), its vector Myndus taffini appears to be endemic to Vanuatu and specific to the disease. However, the host plant Hibiscus tiliaceus is present in all tropical Pacific islands. With the increase in international travel and the consequences of climate change, and despite the ban on export of coconut germplasm from Vanuatu unless it has been properly indexed for CFDV (Frison et al. 1993), the risk of spread of the virus and of its vector outside Vanuatu should be considered. If this occurs, most of the coconut cultivars outside Vanuatu will be seriously affected by CFD. A conventional breeding programme, such as the one developed in Vanuatu, will require large amounts of time and land for field tests. It is possible that the availability of powerful genomics tools developed in the past decade will facilitate studies on the genetic determinism and the mechanism of tolerance to CFD, and speed up future research on tolerance to coconut foliar decay disease both in and outside Vanuatu.

\section{Acknowledgements}

We thank the Vanuatu Agricultural Research and Technical Centre, and the Vanuatu Government for their continuous support to coconut research as well as the VARTC coconut division staff, especially MM. Jean-Pierre Tabiusu, Godefroy Buletare, Emerick Tevanu, Pedro Relmal, and Valentino Telukluk, for the tremendous work done during the last four decades. We are also indebted to Dr. Jean-François Julia and Dr. Jean-Paul Morin, both retired CIRAD scientists, who participated in this research programme by setting up the first experiments at the Saraoutou station. The Waite Agricultural Research Institute of the University of Adelaide, the Centre de Coopération Internationale en Recherche Agronomique pour le Développement (CIRAD) and the Australian Centre for International Agricultural Research (ACIAR) were the other main funders of the activities reported in this article. 


\section{References}

Batugal PA, Bourdeix R and Baudouin L (2009) Coconut breeding. In: Mohan Jain S and Priyadarsham PM (eds) Breeding plantation tree crops: tropical species, Springer, New York, pp. 327-375

Been BO (1981) Observations on field resistance to lethal yellowing in coconut varieties and hybrids in Jamaica. Oléagineux 36:9-11

Bourdeix R (1989) La sélection du cocotier Cocos nucifera L. Etude théorique et pratique, optimisation des stratégies d'amélioration génétique. PhD dissertation, Université de Paris Sud Orsay, Paris

Bourdeix R (1991) Une stratégie de sélection du cocotier Cocos nucifera L. II - Amélioration des hybrides Grand x Grand / Coconut Cocos nucifera L. selection strategy. II - Improvement of Tall x Tall hybrids. Oléagineux 46:267-286

Bourdeix R (1993) Rapport scientifique cocotier 1991-1992. Station cocotier Marc Delorme. IDEFOR, Abidjan, Côte d'Ivoire

Calvez C-H, Renard J-L and Marty G (1980) La tolérance du cocotier hybride Local x Rennell à la maladie des Nouvelles Hébrides/ Tolerance of the hybrid coconut Local x Rennell to New Hebrides disease. Oléagineux $35: 443-451$

De Nucé M and Wuidart W (1981) Les cocotiers Grands à Port-Bouët (Côte d'Ivoire). 2- Grand Rennell, Grand Salomon, Grand Thaïlande, Grand Nouvelles-Hébrides / The Tall coconuts at Port-Bouët (Ivory Coast). 2Rennell Tall, Solomon Tall, Thailand Tall, New Hebrides Tall. Oléagineux 36:353-365

Dery SK, Philippe R, Baudouin L, Quaicoe RN, Nkansah-Poku J, Owusu-Nipah J, Arthur R, Dare D, Yankey N and Dollet M (2008) Genetic diversity among coconut varieties for susceptibility to Cape St Paul Wilt disease. Euphytica 164:1-11

Dollet M, Quaicoe R and Pilet F (2009) Review of coconut 'lethal yellowing' type diseases. Diversity, variability, and diagnosis. OCL Oléagineux, Corps Gras, Lipides 16:97-101

Foale MA (1964) Report on a visit to Rennell Island B.S.I.P. to study the coconut population. Typed document. Unpublished

Foale MA (1987) Coconut germplasm in the South Pacific Islands. Australian Centre for International Agricultural Research, Canberra, Australia

Frison EA, Putter C and Diekmann M (1993) FAO/IBPGR technical guidelines for the safe movement of coconut germplasm. FAO/International Board for Plant Genetic Resources, Rome

Hanold D, Landgridge P and Randles J (1988) The use of cloned sequences for the identification of coconut foliar decay disease-associated DNA. J. gen. Virol. 69:1323-1329

Hanold D, Morin J-P, Labouisse J-P and Randles JW (2003) Foliar decay disease in Vanuatu. In: Loebenstein G and Thottappilly G (eds) Plant virus diseases on crops in developing countries, Kluwer Academic Publishers, The Netherlands, pp. 583-596

Julia J-F (1982) Myndus taffini (Homoptera Ciixidae), vecteur du dépérissement foliaire des cocotiers au Vanuatu / Myndus taffini (Homoptera Ciixidae), vector of foliar decay of coconuts in Vanuatu. Oléagineux 37:409-414

Julia J-F, Dollet M, Randles J and Calvez C-H (1985) Le dépérissement foliaire du cocotier par Myndus taffini (DFMT) : Nouveaux résultats/ Foliar decay of coconut by Myndus taffini (FDMT): New results. Oléagineux 40:19-27 
Labouisse J-P, Sileye T, Morin J-P, Hamelin C, Baudouin L, Bourdeix R and Rouziere A (2004) Coconut (Cocos nucifera L.) genetic improvement in Vanuatu: overview of research achievements from 1962 to 2002.

Part 1: Improvement of the Vanuatu Tall by mass selection. OCL Oléagineux, Corps gras, Lipides 11:354-361

Labouisse J-P, Sileye T, Morin J-P, Hamelin C, Baudouin L, Bourdeix R and Rouziere A (2005) Coconut (Cocos nucifera L.) genetic improvement in Vanuatu: overview of research achievements from 1962 to 2002.

Part 2: Improvement of the Vanuatu Tall by hybridization. OCL Oléagineux, Corps gras, Lipides 12:170-179

Miller RG (1981) Simultaneous statistical inference. Springer-Verlag, New-York

Perera L, Perera SACN, Bandaranayake CK and Harries HC (2009) Coconut. In: Vollman J and Rajcan I (eds), Handbook of plant breeding. Vol. 4 Oil crops, Springer, pp. 369-396

R Development Core Team (2009) R: A language and environment for statistical computing. R Foundation for Statistical Computing, Vienna, Austria

Randles J, Julia J-F, Calvez C and Dollet M (1986) Association of single-stranded DNA with foliar decay disease of coconut palm in Vanuatu. Phytopathology 76:889-894

Randles JW, Miller DC, Morin J-P, Rohde W, Hanold D (1992) Localisation of coconut foliar decay virus in coconut palm. Ann. appl. Biol. 121:601-617

Randles JW, Wefels E, Hanold D, Miller DC, Morin J-P and Rohde W (1999) Detection and diagnosis of coconut foliar decay disease. In: Oropeza C, Verdeil JL, Ashburner GR, Cardena R and Santamaria JM (eds) Current advances in coconut biotechnology, Kluwer Academic, Dordrecht/Boston/London, pp. 247-258

Santos GA, Batugal PA, Othman A, Baudouin L and Labouisse J-P (1996) Manual on standardized research techniques in coconut breeding. IPGRI, Rome, Italy

Vanuatu National Statistics Office (2008) Census of agriculture 2007. Vanuatu National Statistics Office, PortVila, Vanuatu

Vanuatu National Statistics Office (2009) Exports by major local commodities value 1999-2008. Vanuatu National Statistics Office

Weightman B (1989) Agriculture in Vanuatu. A historical review. The British Friends of Vanuatu, Cheam, UK

Whitehead RA (1966) Sample survey and collection of coconut germplasm in the Pacific Islands. 30 May-5 Septembre 1964. Her Majesty's Stationery Office, London

Wilson MR (1988) The genus Myndus in the Solomon Islands and Vanuatu and its relation to foliar decay on coconut palm in Vanuatu. Bull. Ent. res. 78:519-526. 


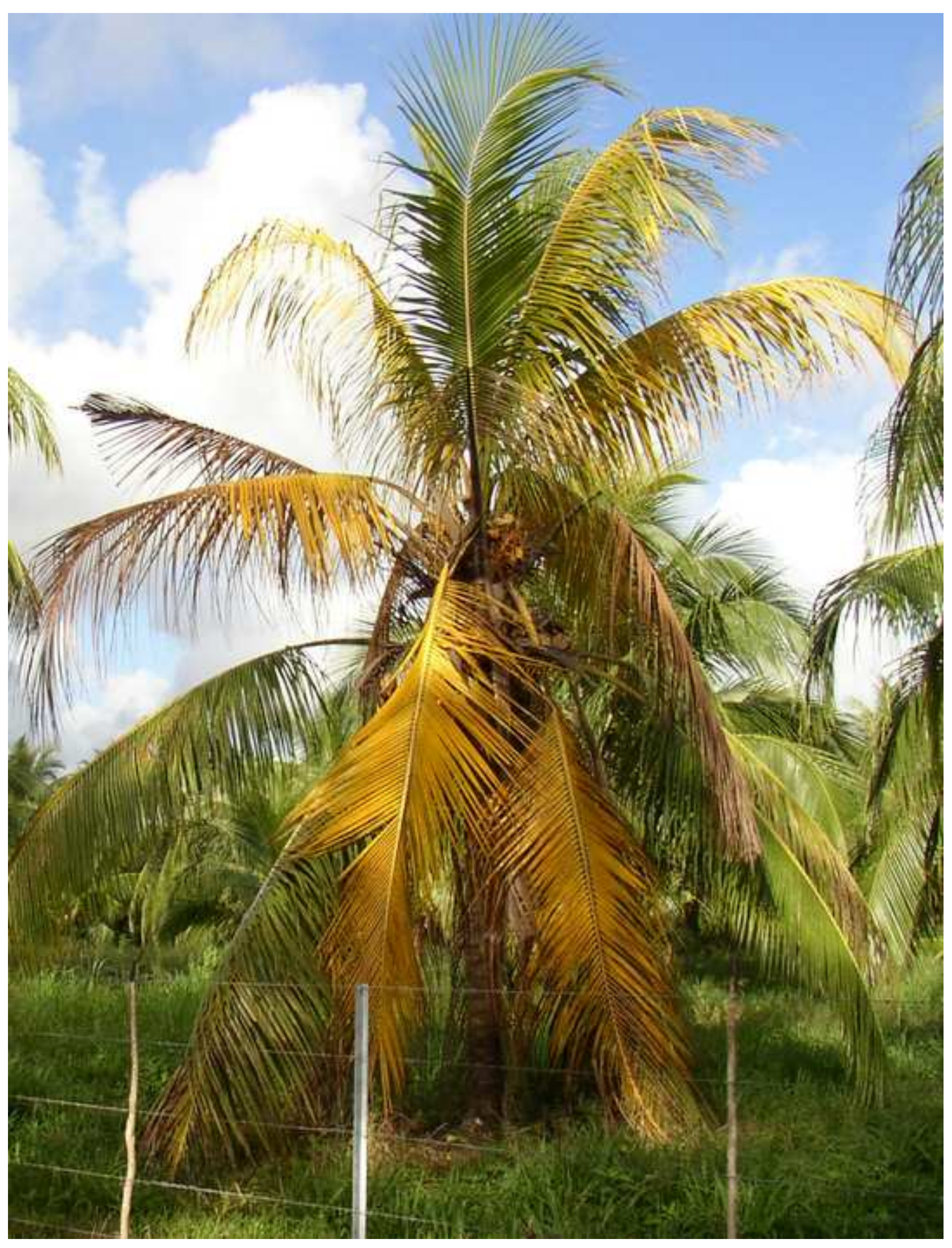

Fig 1 


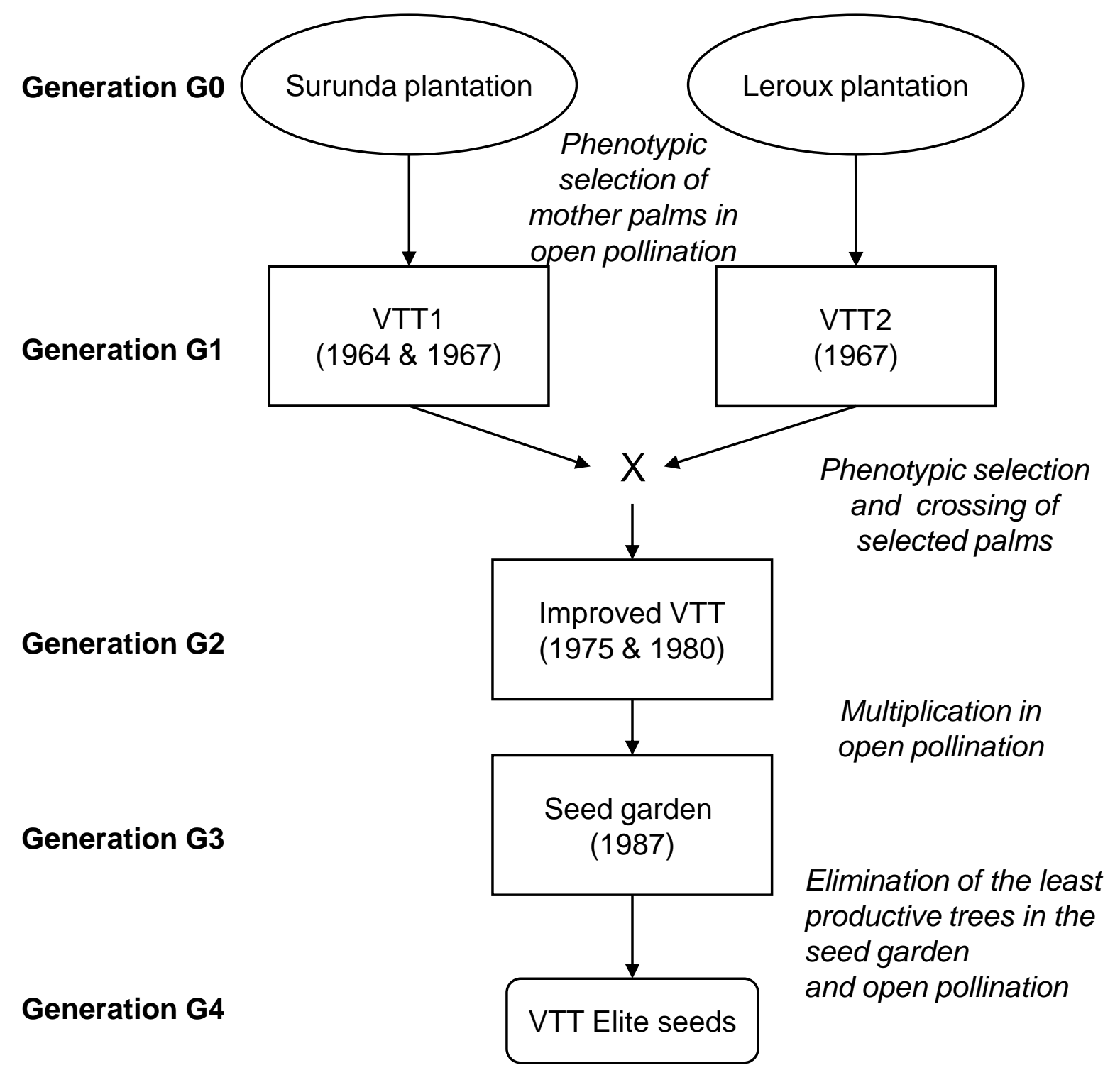




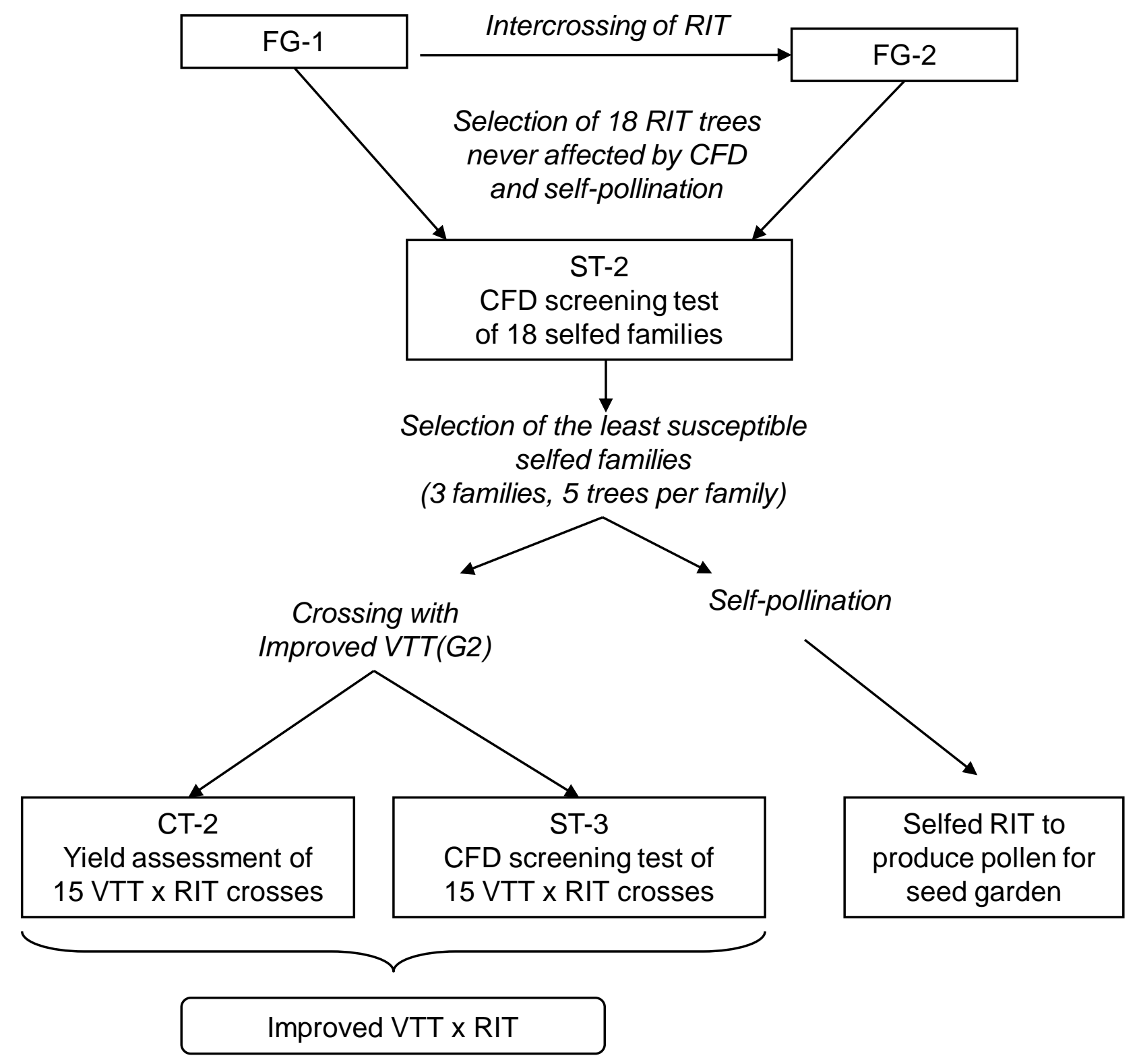




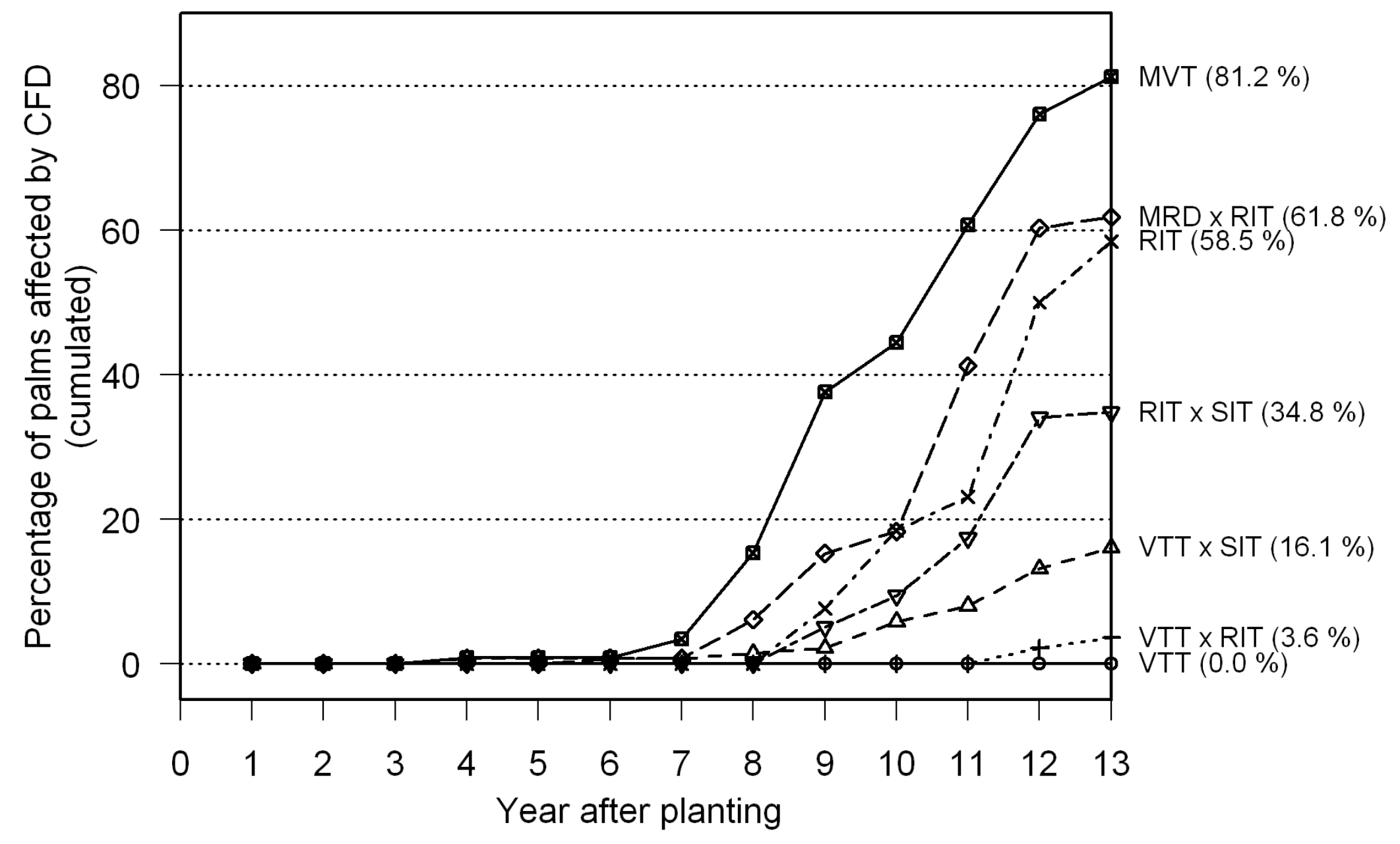




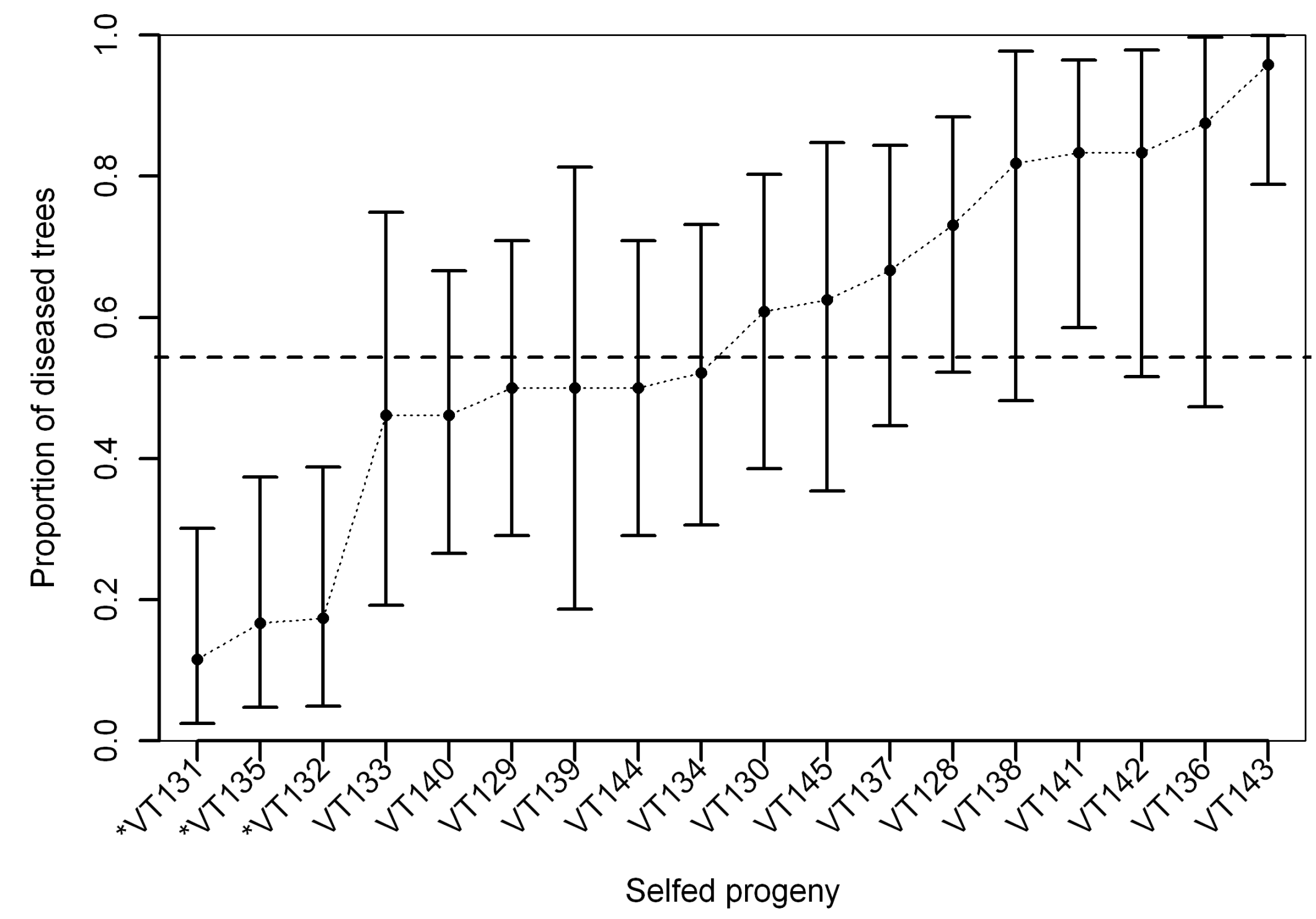




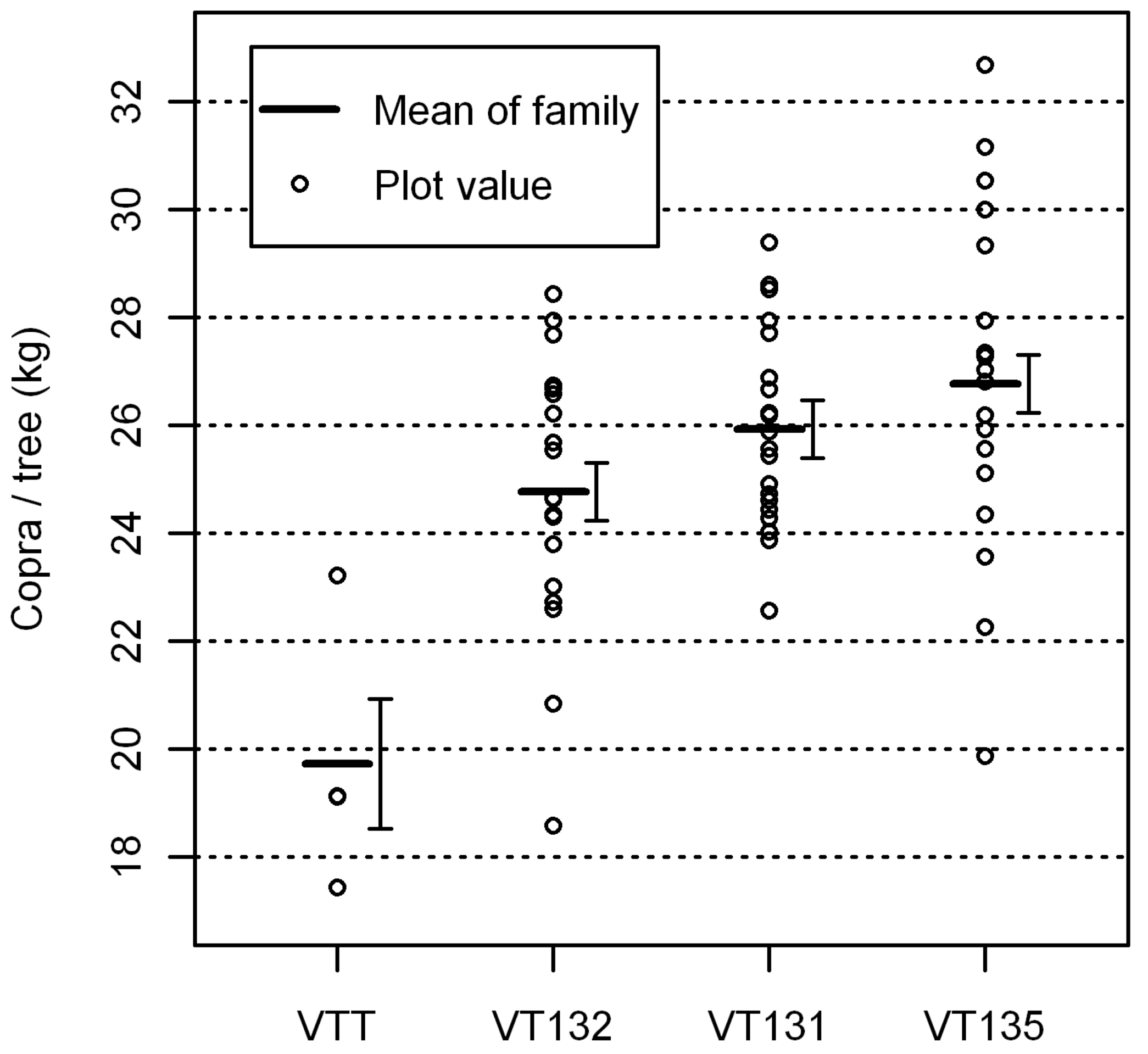

Family 